\title{
ILKYAZ BAYRAMLARI
}

(NEVRUZ - HIDRELLEZ)

\section{Dr. Lütfi SEZEN*}

6 çinde bulunduğumuz Mart ayı, Ön Asya'daki çeşitli topluluklarda yeni yılın başlangıcı, bahar bayramı veya diğer bir ifadeyle, yaz bayramını hatırlatmaktadir.

Nevruz, Türklerde yılbaşı olarak kabul edilen, gece ve gündüzün eşit olduğu 22 Mart günüdür. Türk topluluklarında; Nevruz, Neruz, Navriz, Ergenekon, Çăgan gibi adlarla kutlanmıştır.

Kaşgarlı Mahmut'un Divan ü Lügat'it Türk'unde(1074), 12 aylı Tük takviminde, yılbaşının 21 Mart günü olduğu belirtilmektedir. Bu tarih Nevruz'la aynı güne rastlamaktadır.

Kırım Türkleri Navrez, Başkurtistan'da Navruz, Kazakistan'da Nawrzz, Tataristan'da Navruz, Özbekistan'da Navroz, Türkmenistan'da Novruz, Dogu Turkistan'da Noruz, Kuzey Kıbris Türk Cumhuriyeti'nde Mart Dokuzu olarak isimlendirilmektedir.

Kırgızlar Novruz olarak isimlendirdikleri Nevruz'u yeni yılın ilk günü kabul etmişlerdir.' Uygur Türkleri yeni yılın ilk ayına Aram Ay veya Ram adını vermektedirler. ${ }^{2}$ Altınordu yarluklarında ve Cuvaș Turklerinde; Novruz veya Naurus yeni yılın ilk gïnü karşılığında kullanılmaktadır. ${ }^{3}$ Azerbaycan'da ise, Halkın Aziz Bayramı olarak isimlendirilmekte, Norus veya Noyruz olarak bilinmektedir.

Yusuf Has Hacip, Kutadgu Bilig'de(1069), koc burcunun(21 Mart-20 Nisan) baharın başlangıcı oldugu yazmaktadır. ${ }^{4}$

Nevruz geleneği, doğrudan dogruya Türklerin Ergenekon Destanı ile de ilgilidir. Ergenekon'dan çıkıș günü, Nevruz Günü olarak kabul edilmektedir. Ebulgazi Bahadur Han, Seçere-i Terakime adlı eserinde, bunu teyid etmekte ve daha

* Atatürk Üniversitesi, Kâzım Karabekir Eğitim Fakültesi, Türkçe Eğitimi Bőlümü Öğretim Üyesi.

1 K.K. Yuhadin, Kırgız Sơzlügü, (Çev.: Abdullah Battal Tezmen), Ankara, 1945, s. 585.

2 Ahmet Caferoğlu, Eski Uygur Türkçesi Sőzlügü, İstanbul, 1968, ss. 18-181.

3 Ahmet Caferoð̉lu, "Çuvaşlarda Ay Adları", Halk Bilgisi Haberleri, Sayı: 70(Mayıs, 1931), s. 181 .

4 Yusuf Has Hacib, Kutadgu Bilig I,Metin, Narş R.R. Arat, İstanbul, 1947,Beyit 8,139. 
sonraları, Türk hükümdarlarının bu günü, kızgın ateşle kızdırılan bir demir parçasının, ors üzerinde döverek kutladıklarını kaydetmektedir. ${ }^{5}$

Nevruz günü, eskiden Erzurum ve çevresinde; yumurta günü olarak kutlanılırdı. Özellikle gençler kırlara çıkıp ateş yakar, topluca eğlenir, pişirdikleri yumurtaları ve yemekleri yerlerdi.

Iklim şartları nedeniyle, yaz bayramı törenlerinin yapılması, çeşitli yerlerde tarih değişikliklerine uğramış, farklı tarihlerde uygulama alanı bulmuştur. Miladi 21 Mart tarihine rastlayan Nevruz Yaz Bayramını Anadolu'nun çeşitli yorrelerinde 6 Mayıs günü, benzer tơrenlerle hıdrellez adıyla kutlandığını gormekteyiz.

Nevruz ve hıdrellez bizim milli sembollerimizdendir. Bilindiği gibi, "Milli semboller, tarihin derinliklerine giden, başlangıç noktası açıkça belli olmayan milli ve estetik düşüncelerdir. Bunların yansıması, inançlarla, geleneklerle günümüze kadar gelebilmiştir."6

Türkler, XI. asır sonları ile XII. asır başlarında Anadolu'ya geldiklerinde, ilkbaharda kutlaya geldikleri şenlik ve törenleri de beraberlerinde getirmişlerdir. $\mathrm{Bu}$ törenlerden biri olan Hidrellez, asırlar içinde İslâmiyet'inde etkisiyle giderek zenginleşmiş, Türk'tin ruhuna sinmiş ve benliğine yer etmiştir.

Tưk kưltürủ dışında başka kültürlerde de görülen bahar ve yaz bayramı geleneğinin temelinde, tabiatın canlanması, kışın sona ermesi ve canlanan tabiatın sevinçle karşılanması yatmaktadır. Türk Kültüründe derin izleri bulunan bu gelenek binlerce ylldan beri, gelişerek ve zenginleşerek devam etmektedir.?

Seneyi, Ruz-l Hizir ve Ruz-l Kasim diye iki mevsime ayuran takvimi bilgilere göre, Ruz-ı Hızır, yaz mevsiminin başlangıcı sayılır. 6 Mayıstan 8 Kasım'a kadar süren bu donem, Hızır Günleri adıyla antlmakta, 186 gün sürmekte, miladi takvime göre 6 Mayıs günulne tekabül etmektedir. 9 Kasım - 5 Mayıs tarihlerini içine alan Ruz-ı Kasım kış devresidir. Kasım Günleri olarak adlandırılmakta ve 179 glin sürmektedir.

Günün adlandırılması, ölïmsüzlük suyu içmiş olan Hızır ile llyas'ın bulunmalarının bu güne rastlamasından kaynaklanmaktadır. Halk inanışına göre, Hızır ve İlyas peygamberler, 5 Mayıs'1 6 Mayıs'a bağlayan gecenin sabahında buluşup görüşürler. Bu buluşmanın neticesinde, tabiata hayat, canlılık ve yeşillik gelir. Tabiatla iç içe yaşayan tarım ve hayvancılıkla geçinen yörelerde bu gün, büyük bir sevinçle karşllanmaktadır.

5 Abdulhaluk M. Çay, Hıdrellez Kültür Bahar Bayramı, Kultür Bakanlığı Yayınları, No: 138, Ankara, 1990, s. 15.

6 Abdulkadir M. Çay, "Ergenekon Destanı ve Nevruz Bayramı", Millî Folklor, Bahar, 1995, s.7.

7 Bilge Seyidoglu, “Hıdırellez”, Millî Folklor, Sayr:72, Mayıs, 1990, s.24. 
Hızır ve İlyas adlarının kısaltılmıs şekli daha sonraları, Ruz-ı Hızır (Hızır günui) karışlığında, Hidrellez olarak kullanılmıștır. Bu terim farklı yörelerdeki halk ağızlarında, Idırellez, Iderlez, Ilk Yaz, Izır Bayramı biçiminde söylenmektedir.

Halka göre Hızır, darda kalanların imdadına koşan mübarek bir zattır. İnsanlara servet, bereket, ve kainata yeniden hayat bahşeden bir kudrettir. Günümüzde hastahane cankurtaranlarına "Hızır", acil servislere de "Hızır Servis" denilmesinin özündeki espri bu inanışla ilgilidir.

Anlatılanlara göre bir gün taş üzerinde oturan Hızır, ayağa kalkıp yürumeye başlayınca, kendisi ile birlikte oturduğu taş da hareket etmiş, ayağını bastığı yerlerde çimenler bitmiştir. Bundan dolayı "yeşil" anlamına gelen "Hızır" adını almıştır.

İlyas da Hızır gibi darda kalanların imdadına koşar. Ancak şöhreti Hızır kadar yaygın değildir. O'nun giydikleri Hızır'ın giydikleri gibi süslü ve renkli değildir. Keçi derisinden yapılmış uzun bir gömlek giyer. Uzun boylu, esmer, zayıf görünümlü bir ihtiyardır.

Hıdrellez ve Nevruz uygulamaları Türk insanının bulunduğu her yerde vardır. $\mathrm{Bu}$ uygulamalar, inançlar, efsaneler, ümitlerle dolu ve şiirlerle süslüdür. $\mathrm{Bu}$ çizgi, Balkanlar'dan Anadolu'ya, Kafkasya'dan Asya içlerine kadar uzanmakta, ölmezlik suyu ve baht açma gelenekleri ile devam etmektedir.

\section{HIDRELLEZ PRATIKLERI (UYGULAMALARI)}

Hıdrellez hazırlık ve uygulamalarını çoğunlukla gençler yürütürler. Bu günün pek çok olumlu niteliği yanında, kısmet açan ve mutlu yuvaların kurulmasına zemin hazırlayan yönleri olduğuna da inanılmaktadır.

Hidrellez Uygulamalarını, Hıdrellez Öncesi Hazırlıklar ve Hıdrellez günü pratikleri diye iki başlık altında toplayabiliriz. Ayrıca Hıdrellez günü yapılmaması gereken işler de vardır.

\section{HIDRELLEZ ÖNCESİ HAZIRLIKLARI}

- Hidrellez öncesi, 41 karınca yuvasından alınan toprak, ev halkının para cüzdanına az miktarda konursa, o eve bolluk ve bereket gelir. ${ }^{8}$

8 M. Emine Cingöz, "Eskişehir'de Hıdırellez Kutlamaları", Millî Kültür, Sayı: 72, Mayıs, 1990, s. 6-8. 
- 5 Mayıs'ı 6 Mayıs'a baglayan gecenin sabahında, akarsudan nur akar. Bu suya girenlerin vicudu nurlu olur ve yeniden hayat bulur.

- Evlenmek isteyen delikanlı, özel surette yapılmış tuzlu çöreği 5 Mayıs akşamı yiyerek gece uykusuna yatarsa, ruyasında evleneceği kızı görulr.

- Hıdrellez günủ için ónceden ekmek pişirilir, bu ekmek parçalanmaz. Sofraya tam olarak konur. Tam ekmek ailenin birligini simgeler.

- 5 Mayıs'1 6 Mayıs'a bağlayan akşam, soğanın yeşermiş yapraklarından ikisi aynı boyda kopartılarak her biri için niyet tutulur. Hıdrellez günü bu yapraklardan hangisi daha çok uzarsa, o niyetin gerçekleşeceğine inanılır.

- Cocugu olmayan kadın 5 Mayıs akşamı abdest alıp namaz kıldıktan sonra, bezden yaptığı bebeği, gül ağacının dibine koyarsa çocuğu olur.

- Hasta ve yaşlılar, 5 Mayıs akşamı, çimenlerin üzerinde yuvarlanırlarsa sifa bulurlar.

\section{HIDRELLEZ GÜNÜ HAZIRLIKLARI}

- Hıdrellez gůnủ güneş doğmadan kalkılır. Geç kalanlar, şafak vakti evleri dolaşan Hizir'dan nasiplenemezler.

- Evlenmek isteyen kızlar, Hıdrellez günü kimliklerini belli etmeden, kıbleye bakan 9 komşu kapısını çalarlarsa, kısmetleri açılır.

- Evlenme çağına gelen genç kız, Hıdrellez günü yaptığı tuzlu çöreğin yarısını yer, diğer yarısını da dam veya duvar üstüne bırakır. Kargalar, bu çöreği alıp hangi evin bacasına götürürlerse genç kız o eve, uzağa götürürlerse, uzağa gelin gider.

- Kısmetinin açılmasını isteyen genç kız veya delikanlı Hıdrellez günu, sabah namazından önce kıbleye bakan 7 çeşmeden su içerse o yıl evlenir.

- 6 Mayıs günú sabahı, gün doğmadan sokak kapısı sonuna kadar açılırsa, Hızır eve girer, bolluk, bereket getirir.

- Soğan kabuğu ile kaynatılan yumurta Hıdrellez günú çocuklara yedirilirse, şifa kaynağı olur.

- Hıdrellez günü, boya kısa olan çocuk veya gencin başına bir oklava ile vurulursa, o yıl içinde boyu uzar.

- 6 Mayıs günù seher vakti, bir akarsu kenarında çamurdan ev yapılır, içerisine bugday doldurulursa, o yil mahsul bol olur. 
- Hıdrellez glinù kadınlar, başlarına çimen yeşili örtü örtünürlerse o yıl, bol yağmurlu ve bereketli geçer.

- Ayrıca saçlarını yeşil yaprak ve çimenle süsleyen kızların, saçları iyi uzar.

- Yağ ve ayran yapılan yayıklar (çalkanlar), yeşil dal ve yapraklarla süslenirse, o yayıkta yapılan mahsül bereketli olur. ${ }^{9}$

- 6 Mayıs günü, gözlerine sürme çeken kızların, o yıl başlar_ağ_rmaz.

- Ev sahibi olmak isteyenler, Hıdrellez gününden başlayarak üç gün boyunca, gül ağacının dibine ev maketi yaparlarsa, o yıl ev sahibi olurlar.

- Kırk çiçekten alınan yeşil yapraklar, bir kaptaki suya atılır. Yüzünde sivilce olanlar, bu su ile yıkanırlarsa, sivilceden kurtulurlar.

- Yıl içinde kısmetinin açılıp açılmayacağını ögrenmek isteyen genç kız, tomurcuk halindeki bir çiçeği, suyun içine koyar, ertesi gün tomurcuk açılırsa, kısmeti olur. Açılmazsa, olmaz.

\section{HIDRELLEZ GÜNÜ YAPILMAMASI GEREKENLER}

Anadolu'nun pek çok yöresinde, temizlik ve yemek pişirme gibi işler, Hıdrellez gününe bırakılmaz. Birkaç gün öncesinden yapılır. Hıdrellez günü eğlenme, yeme-içme dışında hiçbir iş yapılmaz. Süpürge tutulmaz, çünkü süpürge tutanların o yıl, sıkıntılı işlerinin çok olacağına inanılır. İğne iplik ele alınmaz ve dikiş dikilmez. Hıdrellez günü eline iğne iplik alıp dikiş dikenler, yıl boyunca kötülüklerle ve yılanlarla karşılaşırlar. Hıdrellez gününü evde geçirmek iyi sayılmaz. Mutlaka ağaçlı, sulu, yeşillik yerlere gidilmelidir. Hızır o gün yeşillik yerlerde nasip dağıtır.

\section{SONUC}

Kaynağını mitolojik dönemlerden alan pek çok uygulama zamanla daha da çŏgalıp zenginleşerek Nevruz, Hidrellez ve benzeri törenlerle günümüze kadar gelebilmiştir. Bu törenlerin yaşatılması ve gelecek kuşaklara aktarılması görevi şimdi bizlere dusşmektedir

9 Numan Kartal, "Kocacıkta Hıdırellez Geleneģi" ,V. Milletlerarası Halk Kültürü Kongresi , Seksiyon Bildirileri, Ankara 1987. 
Birlik ve butünlugüüüzü pekiştirmesi konusunda gerekli duyarlılı̆̆ın gösterilmesi dilegi ile, bütün Türk halkının nevruz yaz bayramın kutluyor, hepinize saygilar sunuyorum. ${ }^{10}$

10 Bu yazı, 21 Mart 1999 Pazar günü saat: 10.00'da Erzurum Valiliği İl Kültürü Müdürlüğ̈u'nce Halk Eğitim Merkezi'nde düzenlenen panelde yapılan konuşmadır. 